DOI: 10.34015/2523-4552.2021.1.06

УдК 343.352

Веретянніков В. О., здобувач Луганського державного університету внутрішніх справ імені Е. О. Дідоренка

ORCID: 0000-0001-7513-2292

\title{
ПРОВОКАЦІЯ ЗЛОЧИНУ В НІМЕЦЬКОМУ КРИМІНАЛЬНОМУ ПРАВІ (ПОРІВНЯЛЬНО-ПРАВОВИЙ АСПЕКТ)
}

Усебічно вивчено досвід ФРН у частині визначення ознак і меж провокаційної поведінки в кримінальному праві. Виявлено, що практика Європейського суду з прав людини стимулювала зміни в підходах німецького касаційного суду щодо тлумачення змісту провокаційної поведінки з боку працівників правоохоронних органів та уповноважених ними осіб. Проаналізовано висловлені в німецькій юридичній літературі критичні аргументи на адресу правозастосовного підходу у вигляді зменшення судом розміру призначуваного покарання у разі встановлення ознак провокації обвинуваченого.

Ключові слова: провокація; Європейський суд з прав людини; правозастосовна практика; агент-провокатор; підбурювання.

Всесторонне изучен опыт ФРГ в части определения признаков и границ провокационного поведения в уголовном праве. Выявлено, что практика Европейского суда по правам человека стимулировала изменения в подходах немецкого кассационного суда относительно толкования содержания провокационного поведения со стороны сотрудников правоохранительных органов и уполномоченных ими лиц. Проанализированы высказанные в немецкой юридической литературе критические аргументы в адрес правоприменительного подхода в виде уменьшения судом размера назначаемого наказания в случае установления признаков провокации обвиняемого.

Ключевые слова: провокация; Европейский суд по правам человека; правоприменительная практика; агент-провокатор; подстрекательство.

Постановка проблеми. Питання юридичної оцінки провокації злочину $\epsilon$ актуальними для більшості європейських держав, зокрема для України та ФРН. Ураховуючи потужний і усталений нормативний, науковий i правозастосовний фун- дамент кримінально-правового регулювання у Німеччині, досвід саме цієї держави в частині визначення ознак і меж провокаційної поведінки видається особливо корисним для опрацювання вітчизняною кримінально-правовою доктриною. 
Наразі в європейських країнах таємні агенти (провокатори) регулярно долучаються до розкриття злочинів, у т.ч. корупційних. Так, повідомлялося, що завдяки негласним слідчим діям в європейських країнах розкривається 85\% тяжких злочинів. При цьому в США, наприклад, результати таких дій визнаються належними доказами в суді в 95\% випадків, а в Україні - лише в 5\% [1]. Причиною цьому вочевидь $€$ як недосконалість вітчизняного законодавства (матеріального і процесуального), так і незадовільна практика його застосування. За таких обставин важливого значення набуває відповідна практика ЄСПЛ.

Водночас потрібно констатувати, що питання щодо поняття, змісту провокації, а також щодо її застосування у боротьбі зі злочинністю зберігають частку дискусійності в теорії та практиці не лише серед вітчизняних, а й серед зарубіжних фахівців.

Аналіз останніх досліджень та публікацій. Серед німецьких (та загалом європейських) авторів феномен провокації в кримінальному праві загалом і проблеми провокації корупційних правопорушень зокрема активно досліджували Ф. Герліц, Дж. Губерт, Ж. Кучер, М. Шеффер, П. Візер, Д.Хілл, С. Маклауд, А. Тані, Л. Леванон, П. Маруцкі, І. Роксін.

В Україні кримінально-правові аспекти провокаційної поведінки, зокрема в частині провокації підкупу, ставали предметом досліджень П. Андрушка, О. Альошиної, С. Бабич, О. Бантишева, Т. Батраченко, Ю. Бауліна, Б. Волженкіна, Ю. Гродецького, О. Грудзура, О. Дудорова, Н. Єгорова, П. Загодіренка, К. Задої, В. Киричка, В. Комар, О. Лемешка, М. Мельника,
В. Навроцького, В. Осадчого, О. Охотнікової, А. Панової, С. Радачинського, В. Трепака, М. Хавронюка та деяких інших.

Постановка завдання. Метою написання наукової статті стало критичне вивчення актуального правозастосовного досвіду та доктринальних напрацювань у ФРН щодо визначення ознак і меж провокаційної поведінки в кримінальному праві, а також часткове порівняння німецької моделі провокаційної поведінки зі змістом провокації у вітчизняному кримінальному праві (передусім у межах діяння, описаного в ст. 370 КК).

Виклад основного матеріалу. Як пише М. Погорецький, наукова розробка проблематики провокації злочину, доцільності й правомірності іiі застосування у протидії злочинності найбільш продуктивно почалася лише у середині XIX ст., коли у 1844 p. німецький криміналіст М. Брейденбах (Breidenbach) уперше провів кримінально-правовий аналіз провокації на основі сформованої в кінці XVII ст. у Франції практики використання методів провокації за допомогою засилання поліцейських агентів у злочинний світ, надававши цьому поняттю виключно політичне значення. Він уважав, що провокацію утворює діяльність таємної агентури, а саме таких суб'єктів, яких уряд скеровує на штучне збудження заворушень для того, щоб, використовуючи ïx, мати можливість (привід) організовувати державні перевороти або вдаватися до надзвичайних заходів управління, які неможливі в мирний час. 3 урахуванням зазначеної мети діяльності агентів поліції Брейденбах для відображення специ- 
фіки іï смислового значення до слова «агент» додав додаток «провокатор». Поєднання слів «агент-провокатор» стало активно вживатися у відповідних наукових дослідженнях XIX$\mathrm{XX}$ ст., незважаючи на те, що в розуміння діяльності агента-провокатора вченими вкладався різний зміст. Таким чином, метою провокатора, на думку М. Брейнденбаха, була не передача злочинців у руки правосуддя, а створення умов для здійснення «революції згори» та розправа 3 небажаними уряду особами неправовими методами, за допомогою створення надзвичайної обстановки [2, с. 35].

За словами німецького криміналіста К. Людерсена, оберігати осіб, схильних до кримінальних злочинів, від остаточного падіння саме по собі $\epsilon$ зловживанням, несумісним з повагою людської гідності та суперечить соціальним задачам держави [3, c. 220].

Наразі німецький кримінальний закон не визначає, які саме прояви поведінки утворюють провокацію, і тим більше не орієнтує правозастосувача на межі правомірності/неправомірності провокації. Відповідно, певні орієнтири щодо умов правомірності провокації закріплені в окремих приписах кримінально-процесуального законодавства ФРН. Так, зокрема, ст.ст. $110 \mathrm{a}, 110 \mathrm{~b}$ та 110 с Кримінально-процесуального кодексу (нім. Strafprozeßordnung) цієї держави регламентують процесуальний статус та повноваження поліцейських агентів під прикриттям під час розслідування окремих категорій злочинів. Хоча корупційні правопорушення безпосередньо не згадані у відповідному переліку діянь, водночас вони можуть охоплюватися поняттям злочину, що вчиняється на комерційній чи регулярній (повторній) основі (ст. 110а(1)) [4].

у загальних рисах у ФРН під провокацією розуміється не схиляння законослухняного громадянина до вчинення злочину, а прагнення змусити особу, яка вже готується до вчинення злочину, діяти в невигідних для себе умовах і тим самим полегшити завдання затримання та викриття правопорушника. Німецькі юристи виходять із того, що за вчинення провокаційних дій агент не підлягає покаранню, адже він спрямовує свої зусилля не на кінцевий результат злочину, а лише на ззовні контрольовану спробу його вчинити іншою особою та з метою запобігання більш небезпечним наслідкам [5, c. 168].

Отже, варто зафіксувати тезу про те, що сучасне німецьке кримінальне право наполягає на законності методу провокації. Такий підхід обумовлений, на думку німецьких правників, передусім тлумаченням змісту ст. 20(3) Основного закону ФРН, в якій зафіксовано принцип верховенства права (нім. Rechtsstaatsprinzip) в державі, який, своєю чергою, вимагає ефективного кримінального переслідування уповноваженими органами, водночас із суворим додержанням конституційних засад кримінального процесу.

Цікаво, що Федеральний Верховний Суд ФРН (нім. Bundesgerichtshof, далі - ФВС) визнав провокацію як можливе порушення статті 6 ЄКПЛ, однак при цьому виступив проти тотальної заборони провокаційної діяльності в правоохоронній практиці [6].

Німецькі коментатори визнають, що практика ЄСПЛ виступила 
каталізатором зміни підходів німецького касаційного суду в частині тлумачення ознак і меж провокаційної поведінки. Зокрема суди ФРН відтепер також розрізняють допустимі і недопустимі прояви провокації, що, відповідно, мають різні юридичні наслідки. Так, відповідно до правових позицій ФВС провокація дозволяється, якщо обвинувачений раніше притягувався до відповідальності (або принаймні підозрювався) за протиправні діяння, схожі на те, щодо вчинення якого застосовується провокація. Своєю чергою, Федеральний конституційний суд ФРН (нім. - Bundesverfassungsgericht, далі - ФКС) проводить межу між допустимою та недопустимою провокацією шляхом визначення оптимального для правової держави балансу між правом особи на справедливий суд (ст. 6 ЄКПЛ) та публічним (суспільним) інтересом у частині забезпечення ефективного розслідування та покарання злочинів [7, с. 498].

Допустимими, тобто не розбіжними 3 нормами правової держави, провокаціями злочину вважаються ті, які прагнуть викрити вже підозрюваних у вчиненні злочину осіб, тобто коли $€$ обгрунтовані припущення про те, що злочинець i без провокації вчинить протиправну дію; мета провокації в такому випадку полягає лише в направленні перебігу злочину у вигідне для виявлення доказів русло. При цьому сучасна судова практика ФВС визнає навіть допустиму провокацію пом'якшувальною обставиною, яка повинна відбиватися у реальному пом'якшенні покарання (на тій підставі, що спровокований злочин утворює лише незначну небезпеку, оскільки відбувається під контролем поліції). Неприпустимою, тобто такою, що переступає принципи правової держави, визнається провокація, коли особа приймає рішення вчинити злочин виключно під впливом (за результатами) такої провокації.

$\mathrm{y}$ той час як ФКС при такій провокації вважає за можливе (хоча і у виняткових випадках) припинення судового розгляду, «беручи до уваги гідність людини і принципи правової держави», ФВС, який безпосередньо впливає на судову практику у кримінальних справах, останнім часом дотримується позиції, відповідно до якої подібна провокація повинна в кожному конкретному випадку розцінюватися лише як «вагома, така, що не залежить від вини, підстава для визначення розміру покарання», що за певних передумов (наприклад, при особливо сильному впливі агента-провокатора на виконавця злочину і водночас при незначній тяжкості злочину) може навіть призвести до припинення судового розгляду зв'язку з малозначністю протиправного діяння (§ 153 КПК) [8, с. 14.].

Допустимою провокацією злочину за кримінальним законодавством ФРН визнається така провокація, яка ставить перед собою завдання викриття підозрюваного у вчиненні злочину, який він вчинив би і без провокації. У цьому випадку мета провокації полягає у створенні таких умов вчинення злочину, в яких представляється можливим його документування та збирання необхідних доказів. Натомість неприпустимою визнається така провокація, під впливом якої особа ухвалює рішення про вчинення злочину.

3 метою недопущення зловживань $з$ боку поліції німецьким 
законодавцем було передбачено низку спеціальних заходів. Зокрема, оперативному працівникові під страхом персональної відповідальності заборонено залучати до співробітництва за власним розсудом агента-провокатора. Питання про його допуск у кожному конкретному випадку узгоджується 3 керівником кримінальної поліції та повинно бути авторизоване прокурором. При цьому німецькі правники виходять із того, що агент за вчинення підбурювальних дій не підлягає покаранню, тому що він прагне не кінцевого результату злочину, а лише його спроби з метою відвернення більш небезпечних наслідків [5, c. 168].

Показово, що у ФРН як «провокатори» можуть використовуватися довірені особи (в американській практиці правозастосування таких осіб іменують інформаторами, про що йтиметься у наступному підрозділі).

Зазвичай перед такими агентами поліція ставить за мету досягнення певних завдань, до яких можна, наприклад, віднести: перевірку обгрунтованості підозри у відношенні особи, яка здійснює готування до вчинення злочину або вже вчиняє такий злочин; оцінку ступеня небезпеки особи для суспільства, а також його готовності до вчинення злочинів; пошук форм цілеспрямованого керування поведінкою особи з метою ії викриття.

Відповідно до позиції Верховного федерального суду ФРН, поняття довіреної особи охоплює не лише людину, яка одержує інформацію, що цікавить поліцію, від третіх осіб завдяки своїй професії, наприклад, водія таксі, власника пивного бару, готелю тощо, але й людину, яка одержує ін- формацію завдяки тому, що вона належить чи належала до злочинного середовища або проникла до нього 3 метою отримати чи передати свідчення, необхідні поліції, безоплатно або за винагороду. Також органи кримінального переслідування надають гарантії довіреній особі щодо збереження таємниці їі діяльності. Поліція не розголошує імені інформатора, довіреної особи, проте вона використовує повідомлені ними факти в процесі розслідування злочину [9, c. 40].

Попри значний суспільний резонанс навколо проблематики провокації в німецькій правоохоронній практиці, агенти-провокатори не підлягають кримінальній відповідальності. За відсутності окремої кримінально-правової норми, яка би регламентувала порядок притягнення провокаторів до кримінальної відповідальності, питання щодо визначення юридичних наслідків провокаційної поведінки покладені на суди.

При цьому німецька судова практика пропонує лише деякі, досить поверхневі й неточні, критерії розмежування. Як випливає з результатів відповідного судового тлумачення, провокація буде кримінально караною поведінкою лише в тих випадках, коли вона має ознаки підбурювання. Наразі доктрина і судова практика відхиляє наявність таких ознак у разі провокування злочинних, зокрема корупційних, дій агентом-провокатором, оскільки лише той може бути притягнутий до відповідальності за підбурювання, хто мав твердий намір підштовхнути іншу особу до вчинення злочину.

Водночас спровокована особа зазвичай підлягає кримінальному 
переслідуванню - відповідальність виключається лише в тих випадках, коли агент-провокатор шляхом багаторазових, тривалих умовлянь, інтенсивного, наполегливого впливу настільки сильно впливав на нього, що на фоні такої агресивнопровокаційної поведінки агента власний внесок провокованої особи стає умовно другорядним, побічним $[10$, с. 92]. Очевидно, як слушно зауважено в літературі, довести ступінь інтенсивності впливу в окремих випадках надзвичайно складно, якщо взагалі можливо. При цьому в Німеччині навіть за наявності доведеного інтенсивного впливу агентапровокатора на злочинця, відповідні дії визнаватимуться незаконними лише в тому випадку, коли злочиннопідбурювальна поведінка агента 3 очевидністю дискредитує державу та іï інститути [11, с. 167].

Ураховуючи викладене, варто підтримати М. Зубрицьку в тому, що важливим юридичним аспектом виявлення факту провокації злочину є, зокрема, встановлення характеру розмови між працівниками правоохоронних органів та особою, яку схиляють до вчинення злочину. Адже зміст та інтенсивність такої розмови можуть указувати саме на послідовне, наполегливе спонукання до вчинення корупційного кримінального правопорушення. Проте, зауважує згадана авторка, на сьогодні в Україні питання проведення лінгвістичних експертиз у справах про провокацію злочинів залишається малодослідженим у кримінально-правовій доктрині та малозастосовним у судовій практиці [12, с. 336].

Таким чином, у ФРН факт провокації злочину у кримінально- правовому сенсі має негативні наслідки лише для злочинця. Проте, ФВС оцінює провокацію злочину, у т.ч. корупційного, з боку правоохоронних органів як діяння, вчинене за пом'якшуючих обставин: у такому разі тяжкий злочин повинен отримувати юридичну оцінку як злочин середньої тяжкості. Як обгрунтування для такого суттєвого пом'якшення відповідальності зазначено, що спровокований злочин утворює відносно невелику небезпеку, оскільки вчиняється під контролем поліції. При цьому допустимими, такими, що не розходяться з нормами правової держави, вважаються такі провокації, які мають на меті викрити уже підозрюваних у вчиненні злочину осіб, тобто коли наявні обгрунтовані припущення про те, що особа напевне вчинить злочин і без провокації. Метою провокації в такому разі стає всього лише спрямування «розвитку» злочину у вигідний для виявлення доказів напрям [13, с. 109].

у порівняльному контексті О. Кваша виступає за проведення окремого дослідження на предмет доцільності віднесення провокації кримінального правопорушення до обставин, які пом'якшують покарання. Адже, додає вчена, проблема юридичної природи провокації та їі кримінально-правової оцінки на сьогодні $\epsilon$ важливою та актуальною, адже спровокувати можна на вчинення фактично будь-якого протиправного діяння, а не лише корупційного [14, с. 425-426].

Водночас у німецькій юридичній літературі висловлюється послідовна критика на адресу правозастосовного підходу у вигляді зменшення призначуваного покарання у разі встановлення ознак 
провокації особи. Так, І. Роксін та П. Макруцкі пишуть про те, що прояви як допустимої, так і недопустимої провокації можуть виступати підставою для зменшення покарання судом. Водночас установлення судом недопустимої провокації не призводить до особливих юридичних наслідків для спровокованого: відповідно до позиції ФВС у такому разі призначуване спровокованій особі покарання просто буде суттєво меншим порівняно з покаранням за злочин, який було спровоковано в допустимих межах $[15$, с. $174 ; 16$, с. 256]. I все. Очевидно, що такий підхід до диференціації порядку призначення покарання за спровокований злочин важко сприйняти як досконалий.

Упродовж кількох останніх десятиріч ФВС розробив низку критеріїв, які повинні враховуватись під час вирішення питання про те, чи була провокація допустимою. До цих критеріїв варто віднести inter alia: обгрунтована заздалегідь сформована підозра проти провокованої особи, інтенсивність та мета зовнішнього впливу на таку особу, готовність (схильність) підбурюваної особи вчинити протиправне діяння. Кожен 3 цих критеріїв має вагому роль у контексті правозастосування. Водночас ФВС так і не спромігся сформулювати чітко визначений перелік умов, наявність яких указуватиме на провокацію. Натомість тут можна застосувати лише аналіз рішень у конкретних кримінальних справах, у яких провокацію було визнано неприпустимою, i, отже, було визнано обставиною, що пом'якшує покарання. Справді, у німецькій правозастосовній практиці в переважній більшості випадків юридичним наслідком застосування провокації з боку правоохоронців $€$ суттєве зменшення призначеного покарання - зазвичай до рівня мінімального розміру покарання, установленого в законі за конкретний злочин [17, с. 502-503].

Сучасний приклад із практики Європейського Суду щодо юридичного змісту недопустимої провокації, яка мала місце в діяльності німецьких поліцейських, знаходимо у справі «Akbay and Others v. Germany», яка стосувалася засудження чоловіка першої заявниці, який помер (Н. А.), а також другого і третього заявників за контрабанду наркотичних речовин, а також тверджень заявників про те, що їх спровокували працівники поліції.

Як випливає 3 фактичних обставин цієї кримінальної справи, у серпні 2011 р. Н. А., другий і третій заявники були затримані за контрабанду 100 кг кокаїну. Н. А. разом із другом (другий заявник) організували ввезення наркотичних речовин через знайомих останнього. Працівник порту, який насправді був поліцейським під прикриттям, запропонував безпечний канал для їх перевезення. Третій заявник був найнятий Н. А. для того, щоб забрати наркотики з попередньо орендованої квартири та перевезти їх до Берліну.

У листопаді 2012 року регіональний суд Берліну визнав Н. А. винним у незаконному імпорті та обігу наркотичних речовин, а другого й третього заявників було визнано винними за пособництво у вчиненні Н. А. злочину. Засудження заявників головним чином обгрунтовувались їхніми зізнавальними показаннями, допитом агента під прикриттям та показаннями працівників поліції, які працюють з інформато- 
рами. Водночас суд зауважив, що Н. А. та другий заявник були підбурені працівниками поліції до вчинення злочинів, унаслідок чого істотно зменшив призначені їм покарання. Суд також установив, що поліція не підбурювала до вчинення злочину третього заявника, проте загалом пом'якшив призначене йому покарання.

Суд зазначив, що в контексті питання непрямої провокації, а саме ситуації, за якої особа безпосередньо не контактує з працівниками поліції, які працюють під прикриттям, проте залучається до вчинення правопорушення співучасником (Н. А.), якого безпосередньо спровокували органи поліції на вчинення злочину, на основі ретельного аналізу своєї попередньої усталеної практики Суд запровадив тест для оцінки непрямої провокації: (а) чи було передбачуваним для поліції те, що особа, безпосередньо схиляється до вчинення злочину, буде контактувати 3 іншими особами для участі у злочині; (b) чи визначалася діяльність цих осіб також поведінкою поліцейських (c) чи розглядали національні суди цих осіб як співучасників злочину (пункт 117 рішення) [18].

Застосовуючи усталену методологію щодо виявлення ознак провокації до скарг першого та другого заявників, Суд погодився 3 національними судами в тому, що Н. А (безпосередньо) та другий заявник (не безпосередньо) були спровоковані поліцією до вчинення злочинів, за які їх пізніше засудили. Водночас, на думку ЄСПЛ, лише пом'якшення покарань без вилучення всіх доказів, отриманих унаслідок провокації чи застосування процедури 3 аналогічними наслідками, не відповіда- ло вимогам тесту щодо провокації, у зв'язку із чим Суд дійшов висновку про порушення п. 1 ст. 6 Конвенції (право на справедливий суд).

На відміну від цього, грунтуючись на досліджених матеріалах справи, Європейський Суд погодився 3 національними судами в тому, що третього заявника не було спровоковано до вчинення протиправних дій (у вигляді перевезення наркотичних засобів до Берліну). Відповідно, тут ЄСПЛ зробив висновок про відсутність порушення п. 1 ст. 6 Конвенції стосовно третього заявника.

Висновки. За результатами проведеного у межах статті дослідження можна сформулювати декілька узагальнюючих висновків.

По-перше, було встановлено, що протягом декількох останніх десятиріч Федеральний Верховний суд ФРН розробив низку критеріїв, які необхідно враховувати при вирішенні питання про допустимість провокації. Ці критерії повинні включати, серед іншого: обгрунтовану попередньо існуючу підозру щодо спровокованої особи, інтенсивність та мету зовнішнього впливу на таку особу, готовність (схильність) підбурюваної особи до вчинення протиправного діяння.

По-друге, відповідно до положень німецького кримінальнопроцесуального законодавства допустимою визнається така провокація, яка має завданням викрити підозрюваного у вчиненні злочину, який він вчинив би і без провокації. Відповідно, мета провокації полягає у створенні таких умов вчинення злочину, в яких представляється можливим його документування та збирання необхідних доказів. Натомість неприпустимою визнаєть- 
ся така провокація, під впливом якої особа ухвалює рішення про вчинення злочину.

По-третє, законодавчий орган Німеччини вжив, у межах норм процесуального законодавства, низку спеціальних заходів для запобігання поліцейським зловживанням у кримінальних справах про провокацію. Зокрема, поліцейському заборо- няється, під ризиком персональної відповідальності, залучати іншу особу, агента-провокатора, на власний розсуд для вчинення оперативних. Використання агентів-провокаторів повинно бути авторизоване керівництвом поліцейського відділу та погоджуватись із місцевим прокурором.

\section{Список використаних джерел}

1. Григор'єв I. Санкціонований хабар. Закон і Бізнес. Вип. 3. 20-26 січ. 2018 р. URL: $\quad$ https://zib.com.ua/ua/131568-koli_taemniy_agent_stae_provokatorom_i_ peretvoryuetsya_na_zl.html (дата звернення: 05.04.2021).

2. Погорецький М.А. Застосування провокації в ході негласних розслідувань: питання правомірності. Вісник кримінального судочинства: науково-практичний журнал. 2016. № 1. С. 33-43.

3. Адашкевич Ю.Н. Организованная преступность-2 / Под ред. А.И. Долговой, С.В. Дьякова. Москва: Криминолог. Ассоциация, 1993. 320 с.

4. German Code of Criminal Procedure (Strafprozeßordnung - StPO). URL: https://www.gesetze-im-internet.de/englisch_stpo/englisch_stpo.html (дата звернення: 05.04.2021).

5. Гайдук А. П. Зарубежный опыт расследования и раскрытия преступлений в сфере коррупции. Известия Методического центра профессионального образования и координации научных исследований. 1996. № 4. С. 168-174.

6. BGHSt 45, 321 - Tatprovokation durch Vertrauensperson. URL: https://www.servat.unibe.ch/dfr/bs045321.html (дата звернення: 05.04.2021).

7. Görlitz F., Hubert J., Kucher J., Scheffer M., Wieser P. "Tatprovokation" - The Legal Issue of Entrapment in Germany and Possible Solutions. German Law Journal. 2019. № 4 (20). P. 496509.

8. Додонов В.Н. Провокация преступления с позиций современного уголовного права. Вестник Академии Генеральной прокуратуры РФ. 2008. № 3. С. 13-16.

9. Альошина О.І. Провокація (кримінально-правове дослідження) : дис. ... канд. юрид. наук. 12.00.08. Харків, 2007. 204 с.

10. Геснер Р., Херцог У. За фасадом права: методы тайной полиции. Москва : Юридическая литература, 1990.224 с.

11. Радачинский С.Н. Ответственность за провокацию взятки либо коммерческого подкупа : дисс. ... канд. юрид. наук. 12.00.08. Москва, 2002. 188 с.

12. Зубрицька М.В. Провокація злочину у правових позиціях Європейського суду 3 прав людини та у національній судовій системі. Альманах права. 2020. № 11. С. 334339.

13. Иванов Л., Ляммих 3. О новеллах уголовного законодательства Германии, направленных на противодействие организованной преступности. Уголовное право. 1998. № 3. С. 105-113.

14. Кваша О. О. Співучасть у злочині: структура та відповідальність : монограф. Луганськ : РВВ ЛДУВС ім. Е.О. Дідоренка, 2013. 560 с.

15. Roxin I. Die Rechtsfolgen schwerwiegender Rechtsstaatsverstöße in der Strafrechtspflege. München: Verlag V. Florentz, 1988. 300 s. 
16. Makrutzki P. Verdeckte Ermittlungen im Strafprozeß: rechtwissenschaftliche Analyse; rechtsvergleichende Studie mit dem U.S.-amerikanischen Prozeßrecht. Berlin: Duncker und Humblot, 2000. $351 \mathrm{p}$.

17. Görlitz F., Hubert J., Kucher J., Scheffer M., Wieser P. "Tatprovokation” - The Legal Issue of Entrapment in Germany and Possible Solutions. German Law Journal. 2019. № 4 (20). Р. 496-509.

18. Огляд рішень Європейського суду з прав людини (жовтень 2020 року). URL: https://supreme.court.gov.ua/userfiles/media/new_folder_for_uploads/supreme/Ogliad_E SPL_10_2020.pdf (дата звернення: 05.04.2021).

\section{References}

Hryhoriev, I. (2018). Sanktsionovanyi khabar. Zakon i Biznes, 3 [in Ukrainian].

Pohoretskyi, M. A. (2016). Zastosuvannia provokatsii v khodi nehlasnykh rozsliduvan: pytannia pravomirnosti. Visnyk kryminalnoho sudochynstva: naukovopraktychnyi zhurnal, 1, 33-43 [in Ukrainian].

Adashkevych, Yu. N. (1993). Orhanyzovannaia prestupnost-2 / Pod red. A.Y. Dolhovoi, S.V. Diakova. Moskva: Krymynoloh. Assotsyatsyia [in Russian].

Haiduk, A. P. (1996). Gayduk A.P. Zarubezhnyiy opyit rassledovaniya i raskryitiya prestupleniy v sfere korruptsii. Izvestiya Metodicheskogo tsentra professionalnogo obrazovaniya i koordinatsii nauchnyih issledovaniy, 4, 168-174 [in Russian].

Dodonov, V. N. (2008). Provokatsiya prestupleniya s pozitsiy sovremennogo ugolovnogo prava. Vestnik Akademii Generalnoy prokuraturyi $R F$, 3, 13-16 [in Russian].

Aloshina, O. I. (2007). Provokatsiia (kryminalno-pravove doslidzhennia) (Dys. ... kand. yuryd. nauk). Kharkiv [in Ukrainian].

Gesner, R., Hertsog, U. (1990). Za fasadom prava: metodyi taynoy politsii. Moskva: Yuridicheskaya literatura [in Russian].

Radachinckiy, S.N. (2002). Otvetstvennost za provokatsiyu vzyatki libo kommercheskogo podkupa (Dys. ... kand. yuryd. nauk). Moskva [in Russian].

Zubrytska, M.V. (2020). Provokatsiia zlochynu u pravovykh pozytsiiakh Yevropeiskoho sudu z prav liudyny ta u natsionalnii sudovii systemi. Almanakh prava, 11, 334339 [in Ukrainian].

Ivanov L., Lyammih Z. (1998). O novellah ugolovnogo zakonodatelstva Germanii, napravlennyih na protivodeystvie organizovannoy prestupnosti. Ugolovnoe pravo, 3, 105113 [in Russian].

Kvasha, O. O. (2013). Spivuchast u zlochyni: struktura ta vidpovidalnist. Luhansk : RVV LDUVS im. E.O. Didorenka [in Ukrainian].

V. Veretyannikov, Degree seeker at Luhansk State University of Internal Affairs named after E. O. Didorenko

ORCID: 0000-0001-7513-2292

\section{Crime provocation in German criminal law (comparative legal aspect)}

The article elaborates in detail on the experience of Germany in determining the elements and limits of provocative behavior in criminal law. It has been established that the case law of the European Court of Human Rights stimulated changes in the approaches of the German Supreme Court regarding the interpretation of the content of provocative behavior by law enforcement officers and their authorized persons.

84 | С торінка 
It has been established that over the past few decades, the German Supreme Court has developed a number of criteria, which have to be considered when deciding whether a provocation was permissible. These criteria should include, inter alia: reasonable pre-existing suspicion against the provoked person, the intensity and purpose of external influence on such a person, the willingness (propensity) of the incited person to commit an illegal act.

A number of special measures have been taken by the German legislature to prevent police abuse in provocation cases. In particular, a police officer is prohibited from engaging an agent-provocateur at his own discretion under the risk of personal liability. The question of his admission in each case has to be approved by the head of the criminal police and must be authorized by the prosecutor.

Based on a modern example from the case law of the European Court of Human Rights on the legal content of an inadmissible provocation, which had taken place in the activities of the German police, in the drug-trafficking case "Akbay and Others v. Germany, it has been shown that the Court had agreed with the domestic courts that the persons under review had been provoked by the police to commit the crimes for which they were later convicted. At the same time, according to the ECtHR, the mere mitigation of sentences without the removal of all evidence obtained by provocation or the application of a procedure with similar consequences did not meet the requirements of the provocation test, and the Court had established a violation of $\S 1$ of Article 6 of the European Convention on Human Rights.

The critical arguments expressed in the German legal literature against the law-enforcement approach in the form of reduction of the size of the sentence imposed by the court in case of establishing signs of provocation of the accused have been analyzed.

Keywords: provocation; European Court of Human Rights; law enforcement practice; agent provocateur; incitement. 